\title{
FIRST RECORD OF AN INVASIVE LESSEPSIAN MIGRANT, LAGOCEPHALUS SCELERATUS (ACTINOPTERYGII: TETRAODONTIFORMES: TETRAODONTIDAE), IN THE SEA OF MARMARA
}

\author{
Erhan $\operatorname{IRMAK}^{1^{*}}$ and Uğur ALTINAĞAÇ² \\ ${ }^{1}$ Faculty of Fisheries Izmir, Katip Çelebi University, Izmir, Turkey \\ ${ }^{2}$ Faculty of Marine Sciences and Technology, Çanakkale Onsekiz Mart University, Çanakkale, Turkey
}

Irmak E., Altinağaç U. 2015. First record of an invasive Lessepsian migrant, Lagocephalus sceleratus

(Actinopterygii: Tetraodontiformes: Tetraodontidae), in the Sea of Marmara. Acta Ichthyol. Piscat. 45

(4): 433-435.

\begin{abstract}
One specimen of the silver-cheeked toadfish, Lagocephalus sceleratus (Gmelin, 1789), was obtained for first time from the Sea of Marmara, off Gelibolu, by trammel net in October 2008. The morphological features of this species were examined. The presently reported finding also represents the second documented occurrence of a puffer fish in the Sea of Marmara.
\end{abstract}

Keywords: invasion, silver-cheeked toadfish, puffer fish, range expansion, tetrodotoxin

The family Tetraodontidae contributed the highest number of alien fish species in the Mediterranean Sea: Lagocephalus guentheri Miranda Riberio, 1915; Lagocephalus suezensis Clark et Gohar, 1953; Lagocephalus sceleratus (Gmelin, 1789); Torquigener flavimaculosus Hardy et Randall, 1983; Tylerius spinosissimus (Regan, 1908); Sphoeroides spengleri (Bloch, 1785); Sphoeroides pachygaster (Muller et Troschel, 1848); Sphoeroides marmoratus (Lowe, 1938); and Ephippion guttiferum (Bennett, 1831) (see Golani et al. 2002, Corsini et al. 2005, Bilecenoglu et al. 2006, Vacchi et al. 2007, Matsuura et al. 2011). The species belonging to the Tetraodontidae contain tetrodotoxin (TTX), a very potent poison, making them unmarketable because of the associated serious threat to human life and health. Besides, these species also destroy fishing nets and incur economic losses for fishers (Nader et al. 2012). The silver-cheeked toadfish, Lagocephalus sceleratus, is one of the puffer fishes of the Indo-Pacific origin which have invaded the eastern basin of the Mediterranean Sea (Nader et al. 2012). After its first occurrence in the Gökova Bay, Aegean Sea in February 2003 (Akyol et al. 2005), it was reported from the Levantine Sea, Adriatic Sea, Italian coasts of the Ionian Sea, and central Mediterranean, respectively (Kalogirou 2013, Dulčić et al. 2014, Kapiris et al. 2014, Deidun et al. 2015). This paper represents the first record of L. sceleratus from the Sea of Marmara and expands the known distribution of this species.

A single specimen of Lagocephalus sceleratus was caught from Gelibolu coast, Sea of Marmara by trammel net over a sandy bottom at a depth of approximately $6 \mathrm{~m}$ in October $2008\left(40^{\circ} 24^{\prime} \mathrm{N}, 26^{\circ} 40^{\prime} \mathrm{E}\right)$. The sampled specimen was fixed in $4 \%$ formaldehyde solution and deposited in the fish collection of Marine Life Collection Centre of İzmir Katip Çelebi University (IKCMLCC-PIS-01-12-2008) (Fig. 1). Morphomeristic characters of the fish caught were determined following the methodology provided by Smith and Heemstra (1986).

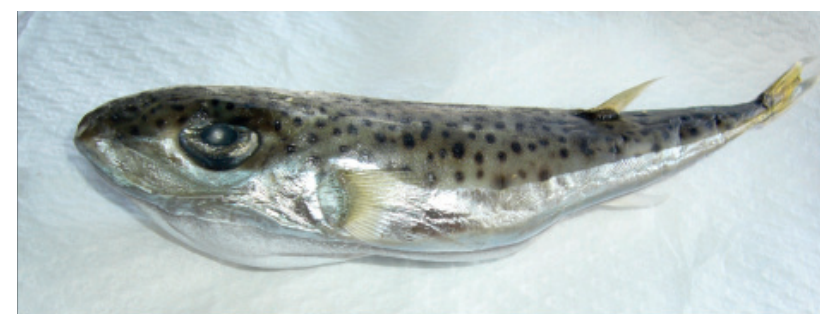

Fig. 1. Specimen of Lagocephalus sceleratus collected from the Sea of Marmara

$$
\begin{gathered}
\text { Family TETRAODONTIDAE } \\
\text { Genus Swainson, } 1839 \\
\text { Lagocephalus sceleratus (Gmelin, 1789) }
\end{gathered}
$$

Description. Body elongate and inflatable; naked but covered with small spinules on belly and sparsely on dorsal surface extending to origin of dorsal fin. Spinules on dorsal part not spinous. Dorsal and anal fins located far posteriorly, containing no spiny rays. Pelvic fins absent; caudal fin lunate. Two quite distinct lateral lines. Gill opening as 
single slit in front of pectoral fins. Dorsal part of body bluish-green with dark spots. Silver coloration from snout to caudal peduncle. Ventral part of body white. Silver triangle blotch anteriorly to eye. Yellowish blotch in middle of caudal fin. Body size: $95.03 \mathrm{~mm}$ total length (TL), 91.02 $\mathrm{mm}$ fork length (FL), $82.24 \mathrm{~mm}$ standard length (SL). Predorsal and preanal length $70.93 \%$ SL and $70.52 \%$ SL, respectively. Eye diameter and preorbital length $36.64 \% \mathrm{HL}$ (head length) and $46.42 \% \mathrm{HL}$, respectively. Dorsal fin rays 12 , anal fin rays 10 and pectoral fin rays 18 . All the other diagnostic features of the specimen were in accordance with Kara et al. (2015), Kalogirou (2013), Milazzo et al (2012), and Akyol et al. (2005).

Remarks. Lagocephalus sceleratus has social and ecological importance due to the presence of tetrodotoxin (Streftaris and Zenetos 2006, Katsanevakis et al. 2014b). The species has powerful jaws that easily cut fishing nets, resulting in a financial loss for fisheries.

Lagocephalus sceleratus obviously showed a successful adaptation following its westward migration into the Mediterranean Sea. After its first occurrence in the Mediterranean it became one of the most common Lessepsian species in the Levantine basin and has showed expansion reaching the northern parts of the Aegean and Adriatic seas and west to Spanish coast (Katsanevakis and Tsiamis 2009). Milazzo et al. (2012), Ben Souissi et al. (2014), and Kara et al. (2015) provided further evidence of its occurrence along north-African coasts. In addition to the above-mentioned records, Katsanevakis et al. (2014a) reported a single specimen from north-western Mediterranean over muddy bottoms in the Ibiza channel, Spain and they confirmed its entry into the western basin of the Mediterranean. In addition, the fast movement to the western basin of the Mediterranean, the silver-cheeked toadfish continues its expansion to the north in the eastern basin. Katsanevakis et al. (2014a) reported the occurrence of $L$. sceleratus in Saros Bay located in northern Aegean Sea. The above-mentioned paper represents the northernmost report from the Aegean Sea of the silver-cheeked toadfish. Low salinity and cold water character of the northern Aegean Sea (principally due to Pontic water coming from the Çanakkale Strait) is an important ecological barrier for the establishment of thermophilic fauna (Por 1978). This barrier is more effective in the Sea of Marmara because it is a transition zone between the Black Sea and the Mediterranean and receives both the Mediterranean waters coming from the Çanakkale strait and the Black Sea waters flowing from the Bosporus. Therefore, there are only three Lessepsian fishes reported from the area. The first one is Lagocephalus spadiceus (Richardson, 1845)-misidentified as Lagocephalus guentheri (see Matsuura et al. 2011) —in Gelibolu coast (Tuncer et al. 2008), the second one is L. sceleratus from Gelibolu coast represented by the presently reported record, and the third one is Stephanolepis diaspros Fraser-Brunner, 1940 from the easternmost part of the Sea of Marmara (Bilecenoglu et al. 2013). Although the records of two puffer fishes are available in the Sea of Marmara there is no evidence of established populations of these species in the area.

The number of the Mediterranean records of Lagocephalus sceleratus - a pufferfish of the Indo-Pacific origin - increases continuously, but published information on its ecological effect follow at much slower pace. Irmak (unpublished*) mentioned that the aggressive expansion L. sceleratus could affect the other species in the shared habitats. This calls for a consistent monitoring of possible changes in the ecosystem and its biodiversity.

\section{ACKNOWLEDGEMENTS}

This study has been a part of the $\mathrm{PhD}$ thesis of the first author. The authors wish to thank the fishermen Yusuf Serim and Ahmet Oktu for providing the material and to Dilruba Seyhan for her assistance.

\section{REFERENCES}

Akyol O., Unal V., Ceyhan T., Bilecenoglu M. 2005. First confirmed record of Lagocephalus sceleratus (Gmelin, 1789) in the Mediterranean Sea. Journal of Fish Biology 66 (4): 1183-1186. DOI: $10.1111 / \mathrm{j} .0022-1112.2005 .00667 . \mathrm{x}$

Ben Souissi J., Rifi M., Ghanem R., Ghozzi L., Boughedir W., Azzurro E. 2014. Lagocephalus sceleratus (Gmelin, 1789) expands through the African coasts towards the Western Mediterranean Sea: A call for awareness. Management of Biological Invasions 5 (4): $357-362$.

DOI: $10.3391 / \mathrm{mbi} .2014 .5 .4 .06$

Bilecenoglu M., Kaya M., Akalin S. 2006. Range expansion of silverstripe blaasop, Lagocephalus sceleratus (Gmelin, 1789), to the northern Aegean Sea. Aquatic Invasions 1 (4): 289-291.

DOI: $10.3391 /$ ai.2006.1.4.14

Bilecenoglu M., Alfaya J.E.F., Azzurro E., Baldacconi R., Boyacı Y.Ö., Circosta V., Compagno L.J.V., Coppola F., Deidun A., Durgham H., Durucan F., Ergüden D., Fernández-Álvarez F.Á., Gianguzza P., Giglio G., Gökoğlu M., Gürlek M., Ikhtiyar S., Kabasakal H., Karachle P.K., Katsanevakis S., Koutsogiannopoulos D., Lanfranco E., Micarelli P., Özvarol Y., Peña-Rivas L., Poursanidis D., Saliba J., Sperone E., Tibullo D., Tiralongo F., Tripepi S., Turan C., Vella P., Yokeş M.B., Zava B. 2013. New Mediterranean marine biodiversity records (December, 2013). Mediterranean Marine Science 14 (2): 463-480.

DOI: $10.12681 / \mathrm{mms} .676$

Corsini M., Margies P., Kondilatos G., Economidis P.S. 2005. Lessepsian migration of fishes to the Aegean Sea: First record of Tylerius spinosissimus (Tetraodontidae) from the Mediterranean, and six more fish records from Rhodes. Cybium 29 (4): 347-354.

Deidun A., Fenech-Farrugia A., Castriota L., Falautano M., Azzurro E., Andaloro F. 2015. First record of the silver-cheeked toadfish Lagocephalus

* Irmak E. 2012. Türkiye kıyılarında Lesepsiyen balon balıkları ve beslenme özellilerinin araştırılması. [Lessepsian puffer fishes on the Turkish coasts and their nutritional properties.] Tez 91/2012. [PhD thesis] Çanakkale Onsekiz Mart Üniversitesi, Fen Bilimleri, Enstitüsü. [In Turkish.] 
sceleratus (Gmelin, 1789) from Malta. BioInvasions Records 4 (2): 139-142.

DOI: $10.3391 /$ bir.2015.4.2.11

Dulčić J., Dragičević B., Antolović N., Sulić-Šprem J., Kožul V., Grgičević R. 2014. Additional records of Lobotes surinamensis, Caranx crysos, Enchelycore anatina, and Lagocephalus sceleratus (Actinopterygii) in the Adriatic Sea. Acta Ichthyologica et Piscatoria 44 (1): 71-74.

DOI: $10.3750 / A I P 2014.44 .1 .09$

Golani D., Orsi-Relini L., Massutí L., Quignard J.-P. 2002. CIESM atlas of exotic species in the Mediterranean. Vol. 1. Fishes. CIESM Publishers, Monaco.

Kalogirou S. 2013. Ecological characteristics of the invasive pufferfish Lagocephalus sceleratus (Gmelin, 1789) in Rhodes, eastern Mediterranean Sea. A case study. Mediterranean Marine Science 14 (2): 251-260. DOI: $10.12681 / \mathrm{mms} .364$

Kara M.H., Ben Lamine E., Francour P. 2015. Range expansion of an invasive pufferfish, Lagocephalus sceleratus (Actinopterygii: Tetraodontiformes: Tetraodontidae), to the south-western Mediterranean. Acta Ichthyologica et Piscatoria 45 (1): 103-108. DOI: 10.3750/AIP2015.45.1.13

Kapiris K., Apostolidis C., Baldacconi R., Başusta N., Bilecenoglu M., Bitar G., Bobori D.C., Boyaci Y.Ö., Dimitriadis C., Djurović M., Dulčić J., Durucan F., Gerovasileiou V., Gokoğlu M., Koutsoubas D., Lefkaditou E., Lipej L., Marković O., Mavrič B., Özvarol Y., Pesic V., Petriki O., Siapatis A., Sini M., Tibullo D., Tiralongo F. 2014. New Mediterranean marine biodiversity records (April 2014). Mediterranean Marine Science 15 (1): 198-212.

DOI: $10.12681 / \mathrm{mms} .737$

Katsanevakis S., Acar Ü., Ammar I., Balci B.A., Bekas P., Belmonte M., Chintiroglou C.C., Consoli P., Dimiza M., Fryganiotis K., Gerovasileiou V., Gnisci V., Gülşahin N., Hoffman R., Issaris Y., IzquierdoGomez D., Izquierdo-Munoz A., Kavadas S., Koehler L., Konstantinidis E., Mazza G., Nowell G., Önal U., Özen M.R., Pafilis P., Pastore M., Perdikaris C., Poursanidis D., Prato E., Russo F., Sicuro B., Tarkan A.N., Thessalou-Legaki M., Tiralongo F., Triantaphyllou M., Tsiamis K., Tunçer S., Turan C., Türker A., Yapici S. 2014a. New Mediterranean biodiversity records (October, 2014). Mediterranean Marine Science 15 (3): 675-695.

DOI: $10.12681 / \mathrm{mms} .1123$

Katsanevakis S., Tsiamis K. 2009. Records of alien marine species in the shallow coastal waters of Chios Island (2009). Mediterranean Marine Science 10 (2): 99-107.

DOI: $10.12681 / \mathrm{mms} .112$
Katsanevakis S., Wallentinus I., Zenetos A., Leppäkoski E., Çinar M.E., Oztürk B., Grabowski M., Golani D., Cardoso A.C. 2014b. Impacts of invasive alien marine species on ecosystem services and biodiversity: A pan-European review. Aquatic Invasions 9 (4): 391-423.

DOI: 10.3391/ai.2014.9.4.01

Matsuura K., Golani D., Bogorodsky S. 2011. The first record of Lagocephalus guentheri Miranda Ribeiro, 1915 from the Red Sea with notes on previous records of L. lunaris (Actinopterygii, Tetraodontiformes, Tetraodontidae). Bulletin of the National Science Museum Series A, Zoology 37 (3): 163-169.

Milazzo M., Azzurro E., Badalamenti F. 2012. On the occurrence of the silverstripe blaasop Lagocephalus sceleratus (Gmelin, 1789) along the Libyan coast. BioInvasions Records 1 (2): 125-127.

DOI: 10.3391/bir.2012.1.2.08

Nader M.R., Indary S., Boustany L.E. 2012. The puffer fish Lagocephalus sceleratus (Gmelin, 1789) in the eastern Mediterranean. EastMed Technical Document No. 10. GCP/INT/041/EC-GRE-ITA/TD-10. EstMed FAO, Athens, Greece.

Por F.D. 1978. Lessepsian migration. The influx of Red Sea biota into the Mediterranean by way of the Suez Canal. Ecological Studies 23. Springer-Verlag, Berlin, Heidelberg, Germany.

DOI: 10.1007/978-3-642-66728-2

Smith M.M., Heemstra P.C. 1986. Smith's Sea Fishes. Smith Institute of Ichthyology Press, Grahamstown, Republic of South Africa.

Streftaris N., Zenetos A. 2006. Alien marine species in the Mediterranean-The 100 'worst invasives' and their impact. Mediterranean Marine Science 7 (1): $87-118$.

DOI: $10.12681 / \mathrm{mms} .180$

Tuncer S., Cihangir H.A., Bilecenoglu M. 2008. First record of the Lessepsian migrant Lagocephalus spadiceus (Tetraodontidae) in the Sea of Marmara. Cybium 32 (4): 347-348.

Vacchi M., Bussotti S., Miglietta A.M., Guidetti P. 2007. Presence of the Guinean puffer Sphoeroides marmoratus (Lowe, 1838) in the Mediterranean Sea. Journal of Fish Biology 71 (4): 1215-1219. DOI: $10.1111 / \mathrm{j} .1095-8649.2007 .01578 . \mathrm{x}$

Received: 25 June 2015 Accepted: 22 October 2015 Published electronically: 31 December 2015 